\title{
Mitochondrial Motility and Vascular Smooth Muscle Proliferation
}

\author{
Susan Chalmers, Christopher Saunter, Calum Wilson, Paul Coats, John M. Girkin, and \\ John G. McCarron \\ Strathclyde Institute of Pharmacy and Biomedical Sciences, University of Strathclyde, Glasgow, \\ United Kingdom (S.C., C.W., P.C., J.G.M.C.); Centre for Advanced Instrumentation, Department \\ of Physics, Durham University, Durham, United Kingdom (C.S., J.M.G.); and Department of \\ Biomedical Engineering, University of Strathclyde Wolfson Centre, Glasgow, United Kingdom \\ (C.W.).
}

\begin{abstract}
Objective-Mitochondria are widely described as being highly dynamic and adaptable organelles, and their movement is thought to be vital for cell function. Yet, in various native cells, including those of heart and smooth muscle, mitochondria are stationary and rigidly structured. The significance of the differences in mitochondrial behavior to the physiological function of cells is unclear and was studied in single myocytes and intact resistance-sized cerebral arteries. We hypothesized that mitochondrial dynamics is controlled by the proliferative status of the cells.
\end{abstract}

Methods and Results-High-speed fluorescence imaging of mitochondria in live vascular smooth muscle cells shows that the organelle undergoes significant reorganization as cells become proliferative. In nonproliferative cells, mitochondria are individual $(\approx 2 \mu \mathrm{m}$ by $0.5 \mu \mathrm{m})$, stationary, randomly dispersed, fixed structures. However, on entering the proliferative state, mitochondria take on a more diverse architecture and become small spheres, short rod-shaped structures, long filamentous entities, and networks. When cells proliferate, mitochondria also continuously move and change shape. In the intact pressurized resistance artery, mitochondria are largely immobile structures, except in a small number of cells in which motility occurred. When proliferation of smooth muscle was encouraged in the intact resistance artery, in organ culture, the majority of mitochondria became motile and the majority of smooth muscle cells contained moving mitochondria. Significantly, restriction of mitochondrial motility using the fission blocker mitochondrial division inhibitor prevented vascular smooth muscle proliferation in both single cells and the intact resistance artery.

Conclusion-These results show that mitochondria are adaptable and exist in intact tissue as both stationary and highly dynamic entities. This mitochondrial plasticity is an essential mechanism for the development of smooth muscle proliferation and therefore presents a novel therapeutic target against vascular disease.

\section{Keywords}

mitochondria; proliferation; remodeling; resistance arteries; smooth muscle

\begin{abstract}
Smooth muscle proliferation is central to vascular hyperplasia and neointima formation in diseases including atherosclerosis and hypertension. Proliferation is also a significant problem that limits the success of cardiovascular disease treatments, including failures of
\end{abstract}

Copyright (C) 2012 American Heart Association, Inc. All rights reserved.

Correspondence to: John G. McCarron, University of Strathclyde, W. C. Bowman Chair of Pharmacology, 16 Cathedral St, Glasgow, United Kingdom. john.mccarron@strath.ac.uk.

Disclosures: None. 
coronary bypass vein grafts and the restenosis that follows balloon angioplasty or stent insertions. ${ }^{1-4}$ New targets and treatments to inhibit vascular smooth muscle proliferation are required.

Mitochondria control virtually every aspect of cell function via changes in ATP concentration, by contributing to $\mathrm{Ca}^{2+}$ signaling, influencing redox potential, and controlling levels of reactive oxygen species. 5,6 The morphology of mitochondria is thought to be essential for the function of the organelle. In some cells, the morphology is complex, and mitochondria exist in a variety of forms in large part because the organelle shows dynamic behavior and may almost constantly change shape and move via Brownian motion, stochastically determined directed motion, long-range motor-driven displacement, fission, and fusion. ${ }^{7-9}$ However, in other cells, the appearance of the organelle is rather simple and exists as ovoid (prolate spheroid) entities that show relatively little movement and are largely unchanging. ${ }^{10-14}$

The significance of the differences in behavior of mitochondria to the physiological function of cells is unclear, but some explanation may come from the various cell types examined. Most studies describing mammalian mitochondrial dynamics have been in cultured cells, particularly in cancerous and immortalized cell lines and cultured neurons, although some have also been carried out in cultured primary or neonatal cell lines, including those of heart, liver, pancreas, and smooth muscle. ${ }^{13,15-17}$ As a result of the emphasis on cultured cells, the role of mitochondrial dynamics in native, differentiated cells and intact tissue is largely unknown. In the cardiovascular system, particularly little is known about mitochondrial movement. In adult heart cells and the intact heart where all the necessary proteins for mitochondrial dynamics to occur are expressed, current research has been unsuccessful in measuring mitochondrial dynamics, that is, there are no reports showing significant mitochondrial movements. The only change detected in adult heart cells has been a restricted Brownian motion, which was attributed to morphological changes of the organelle arising from the contraction and expansion of the mitochondrial matrix (condensed/orthodox transitions). ${ }^{16}$

Interestingly, in the various cultured cells in which mitochondrial dynamics are common, while significant advances have been made on the identity of proteins mediating and regulating mitochondrial movement, an understanding of the physiological purpose and cellular function of mitochondrial dynamics is much more preliminary. The physiological function of one type of mitochondrial dynamics, motor-driven displacement, is probably best appreciated in neurons. Mitochondria are synthesized in the neuronal cell body ${ }^{18}$ and then transported down the axon, which provides a clear purpose for the movement in these rather unusually structured but highly organized cells. ${ }^{19}$ Motor-driven displacement in neurons may also help position mitochondria at locations where energy demand is high. ${ }^{20,21}$ Increases in $\left[\mathrm{Ca}^{2+}\right]_{\mathrm{c}}$ inhibit motor-driven mitochondrial movement ${ }^{22-25}$ to contribute to positioning the organelles where ATP or $\mathrm{Ca}^{2+}$ buffering is required. Yet in other cell types, the physiological function served by motor-driven displacement of mitochondria is poorly understood and mitochondria may not move at all. ${ }^{16}$ Indeed, other than in neurons, ${ }^{25-27}$ mitochondrial movement has not been directly observed in any intact tissue.

Other major forms of mitochondrial dynamics are fission and fusion events which have been linked to apoptosis, maintenance of cellular homeostasis, and mitochondrial quality control via autophagy, but each is unresolved. For example, mitochondrial fission may be involved in the segregation of dysfunctional mitochondria for the organelles' removal by autophagy, ${ }^{28}$ but a lack of mitochondrial fission may lead to increased mitochondrial autophagy. ${ }^{29}$ Mitochondrial fragmentation caused by loss of fusion proteins leads to defects in mitochondrial respiration and oxygen consumption, ${ }^{30}$ yet forced fusion of mitochondria 
also results in a reduction in respiration and oxygen consumption. ${ }^{10}$ Mitochondrial fission may precede apoptosis, ${ }^{31,32}$ although this proposal has also been challenged ${ }^{33,34}$ and enhanced mitochondrial fission does not induce but may protect against apoptosis. ${ }^{35}$ Although contradictory, the results do nonetheless suggest that disturbing dynamics reduces mitochondrial and cell function, although the precise consequences are unclear.

The questions arise as to why mitochondria move in only some cells, whether mitochondrial dynamics are a feature of native intact tissue, and what role the dynamics play in native cell physiology. The present study was undertaken to clarify these issues in native single smooth muscle cells from cerebral resistance arteries and in the intact resistance artery. The data shows that mitochondria are immobile structures in native nonproliferative cells. However, when cells enter a proliferative state, mitochondria become highly dynamic structures. When mitochondrial dynamics were prevented, smooth muscle proliferation was inhibited. We propose that the change in behavior of mitochondria from being rigidly immobile to being highly dynamic is an essential element of vascular smooth muscle proliferation.

\section{Materials and Methods}

An expanded Methods section is provided in the online-only Data Supplement.

\section{Cell Isolation and Culture}

Smooth muscle cells from resistance-sized $(\approx 50-200 \mu \mathrm{m})$ cerebellar and posterior cerebral arteries from male guinea pigs were enzymatically isolated. Cells were stored at $4{ }^{\circ} \mathrm{C}$ for use within 6 hours or were diluted 1:9 in 50:50 Ham F-12 and Waymouth MB752 media supplemented with $10 \%$ fetal bovine serum, $0.1 \mathrm{U} / \mathrm{mL}$ penicillin, and $100 \mu \mathrm{g} / \mathrm{mL}$ streptomycin and grown on $13-\mathrm{mm}$ coverslips in 24 -well plates maintained at $37^{\circ} \mathrm{C}$ in humidified air $\left(5 \% \mathrm{CO}_{2}\right)$.

\section{Intact Artery Preparation and Culture}

To visualize mitochondria, arteries were cannulated and pressurized in an arteriograph and then loaded with $100 \mathrm{nmol} / \mathrm{L}$ tetramethylrhodamine ethyl ester perchlorate (at $36^{\circ} \mathrm{C}$ ). For myogenic tone and intracellular $\left[\mathrm{Ca}^{2+}\right]$ measurement, sections of arteries were loaded with $10 \mu \mathrm{mol} / \mathrm{L}$ Fura2-AM.

\section{Fluorescence Imaging of Cells and Intact Arteries}

Freshly isolated (native) cells or cells grown in culture conditions were loaded with 100 $\mathrm{nmol} / \mathrm{L}$ tetramethylrhodamine ethyl ester, as described previously, ${ }^{11,36}$ or MitoTracker green $(100 \mathrm{nmol} / \mathrm{L}$ for 15 minutes) and imaged on an inverted epifluorescence microscope (Nikon TE2000U) with a $\times 1001.3$ NA S-Fluor oil objective plus internal $\times 1.5$ converter lens. Emitted light was imaged by a Photometrics Cascade 512B camera (Roper Scientific). ${ }^{36,37}$

\section{Image Analysis}

Images were analyzed using Metamorph 7.1.3 (Molecular Devices), ImagePro 7.0 (MediaCybernetics) or the MotionStudio ${ }^{7}$ package. MotionStudio ${ }^{7}$ was used to track individual mitochondria to subpixel accuracy (typically $\approx 10 \mathrm{~nm}$ ) ${ }^{38}$ using an image correlation-based approach. Briefly, in the first frame of a sequence, each mitochondrion was used by the software to create a template. Image correlation was then applied to locate the template within the next frame, ${ }^{7}$ and the template image was then updated to be that of the object in the second frame. The template finding and updating process is repeated for all frames to build up a track of mitochondria positions. Refreshing the template image in each frame accommodates gradual changes in the image of the mitochondria, caused by 
morphological changes, changes in pointing direction of noncircular objects, and photobleaching. Further analysis was performed, including measuring the instantaneous speed and the time-variant displacement of the mitochondria. Displacement was defined as the absolute distance between a mitochondrion's position at a given time and its location in the first frame. The instantaneous speed of the mitochondria was computed by measuring the rate of change of position during 1-second intervals. This interval was chosen as the one long enough to smooth the effects of measurement noise but short enough to accurately determine the speed without averaging out brief, directed motion events. ${ }^{7}$

\section{Measurement of Mitochondrial Area}

Cerebral artery smooth muscle cells were maintained in culture for 4 days in $10 \mu \mathrm{mol} / \mathrm{L}$ mitochondrial division inhibitor (Mdivi-1) or vehicle control ( $0.1 \%$ dimethyl sulfoxide). Contiguous mitochondria were defined as areas that displayed synchronous increases or decreases in tetramethylrhodamine ethyl ester fluorescence highlighted by subtracting a duplicate image stack that was offset by 5 frames (and hence 0.5 seconds) and applying either an inclusive threshold (to detect increases) or exclusive threshold (to detect decreases).

\section{Western Blotting}

Six vessels for each time point were homogenized in $50 \mu \mathrm{L}$ CellLytic M solution (Sigma) using Eppendorf tube pestles. Homogenates were centrifuged and supernatants immediately frozen at $-20^{\circ} \mathrm{C}$ or mixed with $4 \times$ reducing sample buffer and separated by standard SDSPAGE on a $12 \%$ gel, transferred to nitrocellulose membrane, blocked with 5\% BSA for 1 hour, and then incubated with primary antibodies (monoclonal mouse anti-mitofusin-2, polyclonal rabbit anti-proliferative cell nuclear antigen, monoclonal mouse antimitochondrial cytochrome oxidase IV, or polyclonal rabbit anti-GAPDH). Horseradish peroxidase-conjugated anti-mouse or anti-rabbit secondary antibodies were used for visualization using enhanced chemiluminescence.

\section{Immunocytochemistry}

Pressurized (40 $\mathrm{mm} \mathrm{Hg}$ ) arteries were fixed (10\% formalin), permeabilized $(0.5 \%$ Triton $\mathrm{X}-100$ ), and blocked (2\% BSA) before incubating first with rabbit anti-proliferative cell nuclear antigen and then with anti-rabbit-Alexa 488 plus mouse anti-a-actin-Cy3 conjugate before mounting in Vectashield containing 4',6-diamidino-2-phenylindole. Fluorescence images were captured on a Leica SP5 confocal microscope ( $\times 40$ objective) and analyzed (Metamorph 7.1.3).

\section{$\left[{ }^{3} \mathrm{H}\right]$-Thymidine Incorporation Assay}

Cells were grown to $\approx 70 \%$ confluency in 12 -well plates, quiesced for 24 hours in media containing $0.1 \%$ fetal bovine serum, and then returned to media containing $10 \%$ fetal bovine serum for 18 hours. $\left[{ }^{3} \mathrm{H}\right]$-Thymidine $(9.25 \mathrm{kBq})$ was added to each well for the final 6 hours of the 24-hour treatment period. Cells were washed with ice-cold PBS followed by $10 \%$ trichloroacetic acid and then by $10 \%$ sodium dodecyl sulfate in $0.2 \mathrm{~mol} / \mathrm{L}$ sodium hydroxide, and radio-activity was quantified by liquid scintillation (Packard 1500 Tri-Carb or ScintSafe3).

\section{Fluorescence-Activated Cell Sorter Analysis}

Cells were grown to $\approx 70 \%$ confluency in 6-well plates, harvested, resuspended in PBS, and fixed in ice-cold $70 \%$ ethanol at $4^{\circ} \mathrm{C}$ overnight. Cells were then washed with PBS, incubated with $50 \mu \mathrm{g} / \mathrm{mL}$ RNase A for 1 hour at $37^{\circ} \mathrm{C}$, and stained with $40 \mu \mathrm{g} / \mathrm{mL}$ propidium iodide. 
Cell cycle profiles were acquired by flow cytometry (BD FACSDiva software; BD

Biosciences) and analyzed using the software FlowJo.

\section{Statistical Analyses}

Other than Figures 5A and 6, a parametric distribution of raw data around mean values was confirmed before statistical testing. Mean values $\pm \mathrm{SE}$ are shown (unless otherwise indicated) and were analyzed using unpaired Student $t$ tests or, for $>2$ groups, ANOVA with GamesHowell post hoc comparison of variance (for samples with unequal variance). a was set to 0.05 , and $P<0.05$ was considered significant. The median mitochondrial areas with and without Mdivi-1 treatment were compared using a Mann-Whitney $U$ test. The normalized data in Figure 6 were analyzed using Kruskal-Wallis tests, with $P$ values adjusted for multiple testing. $t$ test was carried out in Microcal Origin v6.0, with Bonferroni considerations applied for cell cycle data; all other tests were carried out in SPSS 19 for Windows.

\section{Results}

In native vascular smooth muscle cells, mitochondria were ovoid in appearance and randomly dispersed (Figure 1A); that is, mitochondria showed no pattern or symmetry to their arrangement through the cytosol. There was little evidence for movement arising from motor-driven events (Figure 1A-1E; online-only Data Supplement Information and Video I in the online-only Data Supplement). Indeed, the instantaneous speed of the mitochondria, which was estimated by comparing the organelles' position during 1-second intervals, approached zero (Figure 1F). Over the time course of these experiments, there was no evidence for mitochondria merging or dividing, which suggests that neither fission nor fusion occurred. However, a small restricted mitochondrial movement did occur (Figure 1E). That movement comprised mitochondrial Brownian diffusion and global motion of the host cell but failed to significantly displace the organelle from its center location (Figure 1D) and the overall movement of the organelle (Figure 1C) was insignificant $(<1 \%)$ compared with the size of the mitochondrion (Figure 1D). Thus, mitochondria of native smooth muscle appear rigidly immobile, constrained possibly by cytoskeletal structures (eg, microtubules). ${ }^{39-44}$ However, disruption of microtubules (nocodazole, $10 \mu \mathrm{mol} / \mathrm{L}$ ) did not increase mitochondrial mobility in native cells ( $\mathrm{n}=7 ; P>0.05$; Figure 2A). Together, in native vascular smooth muscle cells, mitochondria appear to be ovoid, stationary, randomly dispersed organelles that are largely immobile.

Interestingly, within 24 hours of maintenance under cell culture conditions in media that contained serum (to promote proliferation), mitochondria in these same cells began to take on a more diverse architecture and range from being small spheres, short rod-shaped structures, long filamentous entities, and networks (Figure 1A and 1B; online-only Data Supplement Information and Video II in the online-only Data Supplement). The majority of mitochondria also became highly dynamic structures and continuously moved and changed shape (Figure 1A-1C, 1E, and 1F; online-only Data Supplement Information and Video II in the online-only Data Supplement). The movement of the organelle (Figure 1C and 1E) was now a significant fraction of the size of the mitochondrion (Figure 1D). Several types of motility occurred, which included bursts of motion that cover large distances, trafficked-like directed motions (in which mitochondria shuttle back and forth along the same path), as well as wriggling and looping movements (Figure 1C; online-only Data Supplement Information and Video III in the online-only Data Supplement). The bursts of movement $(\approx 160 \mathrm{~nm} / \mathrm{s}$; Figure 1C and 1F; online-only Data Supplement Information and Videos II and III in the online-only Data Supplement) correspond to fast, linear travel apparently similar to stochastically determined (molecular motor) driven motion events. ${ }^{7}$ Mitochondrial 
movements in cells in culture were inhibited by treatment with the microtubule-disrupting agent nocodazole $(10 \mu \mathrm{mol} / \mathrm{L} ; \mathrm{n}=8 ; P<0.05)$ but not the actin-disrupting agent lantruculin $\mathrm{B}$ $(10 \mu \mathrm{mol} / \mathrm{L} ; \mathrm{n}=8 ; P>0.05$; Figure $2 \mathrm{~B})$, suggesting that microtubules are required for the motor-driven events.

The transport of mitochondria along microtubules is mediated by the kinesin and dynein families of motor proteins. ${ }^{26,45}$ Kinesin moves with a regular step size of $8 \mathrm{~nm},{ }^{46}$ whereas dynein has a more complex behavior and covers a range of step sizes between 8 and $32 \mathrm{~nm}$, tending toward $8 \mathrm{~nm}$ under load. ${ }^{47}$ These step sizes are significantly smaller than the bursts of motor-driven events observed in the present study. For example, 2 mitochondria in cultured cells move $\approx 100 \mathrm{~nm}$ in 4 seconds (Figure 1E), corresponding to $\approx 13$ motor steps. The largest displacement observed in this example $(500 \mathrm{~nm})$ corresponds to over 60 motor steps. Multiple motors are required to move larger organelles, such as mitochondria, ${ }^{48,49}$ so the bursts of motion imply a significant degree of coordination among the motors, and the velocity of $\approx 160 \mathrm{~nm} / \mathrm{s}$ (Figure $1 \mathrm{C}$ and $1 \mathrm{~F}$ ) is equivalent to $\approx 20$ kinesin steps per second.

Increases in $\left[\mathrm{Ca}^{2+}\right]_{\mathrm{c}}$ arrest mitochondrial motility in $\mathrm{H} 9 \mathrm{c} 2$ myoblasts and cultured primary neurons. ${ }^{50}$ Perhaps the absence of mitochondrial motility in native cells arose from an elevated $\left[\mathrm{Ca}^{2+}\right]_{\mathrm{c}}$; however, lowering $\left[\mathrm{Ca}^{2+}\right]_{\mathrm{c}}$ by removing extracellular $\mathrm{Ca}^{2+}$ did not initiate mitochondrial motility in native smooth muscle cells $(n=5$; Figure $2 \mathrm{~A})$. Neither did replacing the extracellular HEPES-buffered salt solution with culture media containing serum induce motility in native cells (without maintenance in culture, $n=5$; Figure $2 \mathrm{~A}$ ) even at $37^{\circ} \mathrm{C}$ (Figure 2C). Interestingly, the velocities and duration of movement bursts in the cultured cells at $37^{\circ} \mathrm{C}$ increased substantially compared with the movement measured at room temperature (Figure 2; online-only Data Supplement Information and Video IV in the online-only Data Supplement). At $37^{\circ} \mathrm{C}$, the maximum velocities of mitochondria in cultured cells were of the order of $1000 \mathrm{~nm} / \mathrm{s}$, which equates to $\approx 135$ kinesin steps per second. Interestingly, the maximum reported stepping rates for kinesin in the absence of load is $\approx 250$ to 300 steps/second. ${ }^{51}$

The results suggest that native single cells that had been isolated by harsh enzymatic treatment do not show mitochondrial dynamics, whereas smooth muscle cells maintained in conditions (culture) that differ significantly from the normal physiological environment do show mitochondrial dynamics. The question arises as to whether the absence or presence of mitochondrial dynamics is a physiological feature of the organelle. To clarify this issue, we examined mitochondria within the smooth muscle of intact cerebral resistance arteries $(\approx 200 \mu \mathrm{m}$ diameter). The arteries were maintained at physiological pressure and temperature $\left(40 \mathrm{~mm} \mathrm{Hg} ; 36^{\circ} \mathrm{C}\right)$ and in their in vivo geometry (Figure $\left.3 \mathrm{~A}\right)$. These resistance arteries are important for the maintenance of constant cerebral blood flow via the process of myogenic reactivity, in which elevation of intralumenal pressure causes an increase in $\left[\mathrm{Ca}^{2+}\right]_{\mathrm{c}}$ and a decrease in vessel diameter that is maintained until the pressure decreases (Figure 3B). ${ }^{52}$ In the cerebral resistance arteries, the large majority of mitochondria did not move (Figure 3C; online-only Data Supplement Information and Video V in the online-only Data Supplement), however, a small number of mitochondria displayed directed motion like that characteristic of cultured cells.

A major difference between cultured and freshly isolated native smooth muscle is that the former are dividing rapidly, whereas native cells are thought to be largely noncycling and in a quiescent state (although not terminally differentiated and may reenter the cell cycle and proliferate) ${ }^{53,54}$ In the intact artery, there is a constant replacement of old with newly generated cells; perhaps those cells with motile mitochondria are proliferative. To test this possibility, proliferation was encouraged in the intact artery by maintaining segments of intact artery in culture conditions (up to 4 days) with growth factors. In these conditions, 
smooth muscle proliferation increased as measured by 2 separate proliferative markers. Proliferative cell nuclear antigen increased and mitofusin- 2 decreased as measured by immunoblotting (Figure 4C), with no change in mitochondrial numbers (as measured by COX IV, data not shown). Significantly, the increased proliferation was associated with a considerable increase in mitochondrial motility in the intact pressurized arteries. Indeed, the majority of mitochondria in the arteries became motile and the majority of smooth muscle cells contained motile mitochondria (Figure 4A and 4B; online-only Data Supplement Information and Video VI in the online-only Data Supplement). Therefore, it would seem that in intact arteries, like the isolated single cell, there is only a small amount of mitochondrial movement within native adult smooth muscle cells and that proliferation increases both the number of cells that contain motile mitochondria and the number of motile mitochondria themselves.

Perhaps the increase in mitochondrial dynamics is a requirement for proliferation to occur. To test this possibility, we examined whether or not inhibition of mitochondrial motility could prevent vascular smooth muscle proliferation. Mitochondrial motility can be reduced by the small-molecule inhibitor Mdivi-1 ${ }^{55}$ which inhibits dynamin-related protein oligomerization to prevent mitochondrial fission. ${ }^{56}$ Mdivi-1 increases mitochondrial network connectivity and thus decreases mobility. When Mdivi-1 was included in the culture media, the extent of connectivity increased as assessed by the rise in electrical continuity among mitochondria. The increased continuity was measured by transient changes in the mitochondrial membrane potential (flickers) ${ }^{12,57}$ using the membrane potential-sensitive dye tetramethylrhodamine ethyl ester. The median area of individual mitochondrial membrane potential flickers increased in Mdivi-1 (from 1.91 \pm 0.34 to $3.74 \pm 1.40 \mu \mathrm{m}^{2}$, median \pm SD of the median; $P<0.001$ by Mann-Whitney $U$ test), and the fraction of mitochondria with an area $>10 \mu \mathrm{m}^{2}$ increased from $1.3 \%$ to $15 \%$ (Figure $5 \mathrm{~A}$ ). These results suggest that larger areas of mitochondria were in electrical continuity because of Mdivi-1-induced fusion. Mdivi-1 also inhibited mitochondrial dynamics in both isolated single smooth muscle cells (Figure 5B) and intact cerebral resistance artery segments (Figure 5C) that had been maintained in culture for 4 days. A higher concentration of Mdivi-1 was required to inhibit mitochondrial motility in intact arteries than individual cells $(50 \mu \mathrm{mol} / \mathrm{L}$ as opposed to $10 \mu \mathrm{mol} / \mathrm{L}$, data not shown), in agreement with that required to inhibit myocardial infarct size in a mouse model of ischemia-reperfusion injury. ${ }_{58}$

Mdivi-1 inhibited proliferation of cultured resistance artery smooth muscle cells. Three separate experiments confirmed this conclusion. First, Mdivi-1 $(10 \mu \mathrm{mol} / \mathrm{L})$ decreased proliferation as measured by decreased incorporation of ${ }^{3} \mathrm{H}$-thymidine (Figure 6A). Second, Mdivi-1 (10 $\mu \mathrm{mol} / \mathrm{L}$; 48 hours) produced a shift in cell cycle from $\mathrm{S}$ to enrich the G0/G1 phase (Figure 6B and 6C). As a control, an enrichment of the G2/M phase by nocodozole (50 ng/mL; $476 \mathrm{nmol} / \mathrm{L} ; 16$ hours) was confirmed (Figure 6B and 6C). Third, Mdivi-1 also inhibited the increase in proliferation in intact segments of cerebral resistance arteries that were maintained in culture, as measured by immunofluorescence staining of proliferative cell nuclear antigen within the smooth muscle layer (Figure 6C and 6D). Together, mitochondrial dynamics are required for proliferation to occur.

An off-target effect of Mdivi-1 is a possible block of rapidly activating delayed rectifier and acetylcholine-activated $\mathrm{K}^{+}$channels. ${ }^{59}$ Blocking the activity of some types of $\mathrm{K}^{+}$ channels ${ }^{60,61}$ may regulate proliferation, and there is interaction between mitochondrial activity and plasma membrane ion channel expression. ${ }^{6}$ In the present experiments, 4aminopyridine $(10 \mathrm{mmol} / \mathrm{L})$ at a concentration that produces at least an equivalent block of the rapidly activating delayed rectifier $\mathrm{K}^{+}$channels failed to inhibit proliferation as measured by ${ }^{3} \mathrm{H}$-thymidine incorporation (Figure $6 \mathrm{~F}$ ). Block of other $\mathrm{K}^{+}$channels ${ }^{62}\left(\mathrm{Ca}^{2+}\right.$ activated and ATP-sensitive) with tetraethylammonium $(10 \mathrm{mmol} / \mathrm{L})$ and glibenclamide $(10$ 
$\mu \mathrm{mol} / \mathrm{L}$ ) did reduce proliferation (measured by ${ }^{3} \mathrm{H}$-thymidine incorporation; data not shown), although these channels are not reported to be blocked by Mdivi-1. Because acetylcholine exerts little or no effect directly on vascular smooth muscle, the acetylcholineactivated $\mathrm{K}^{+}$channel is unlikely to be expressed.

Rapamycin is used commonly as an antiproliferative agent. In other experiments, intact segments of cerebral resistance artery were maintained in culture for 4 days in the presence of rapamycin $(10 \mu \mathrm{mol} / \mathrm{L})$. However, rapamycin did not inhibit the onset of extensive mitochondrial motility in these vessels ( $n=19$; data not shown). These results suggest that disruption of mitochondrial motility may inhibit the transition of smooth muscle cells to a proliferative phenotype at a stage earlier than rapamycin, potentially preventing their reentry into the cell cycle.

\section{Discussion}

Native, adult smooth muscle cells are largely nonproliferative and in a quiescent state. However, smooth muscle is not terminally differentiated as cells may reenter the cell cycle and proliferate in response to various stimuli, both beneficial (such as angiogenesis) and pathological (such as damage-induced vascular remodeling). ${ }^{53,54}$ In the present study, mitochondria in adult vascular myocytes were ovoid structures and dispersed randomly through the cytosol. The organelle showed only a restricted Brownian motion, which failed to move the mitochondria from its center position, and there was no evidence for motordriven events or fission or fusion. The experiments suggest that mitochondria are rigidly immobile and relatively uniform in appearance in adult vascular myocytes. However, in proliferative vascular cells mitochondria existed as an assortment of shapes, which included small spheres, short rod-shaped structures, long filamentous entities, loops, and networks. There was also extensive mitochondrial mobility, which included large-directed movement and Brownian-like displacement, each of which substantially displaced the mitochondria. We believe this to be the first demonstration of a transition in mitochondrial dynamics as cells change from a native to a proliferative form.

The almost continuous movements and rearrangement of mitochondria are thought to be important for cell function, although the precise role played by mitochondrial dynamics is unclear. Among proposals for the function served by mitochondrial dynamics are that the movement enables recruitment of the organelle to particular subcellular compartments, contributes to the content exchange between mitochondria, or facilitates mitochondrial communication with the cytosol. However, many studies have generated apparently contradictory results (see Introduction section), and because mitochondrial imaging investigations have been carried out frequently in tumor-derived cells with abnormal bioenergetic properties (eg, HeLa and HL-1 cells), the very significance of the dynamics for normal mitochondrial and cell function has been questioned. ${ }^{16}$ Here, mitochondrial dynamics were imaged successfully in real time in intact resistance arteries under physiological artery configurations and pressures. These observations suggest that dynamics are a physiological feature of mitochondria. In the intact artery, there is constant replacement of old with newly generated cells; it may be that cells in which mitochondrial motility occurred are proliferative. Support for this proposal was found in the observation that when proliferation was encouraged in the intact arteries, the number of cells showing mitochondrial movement and the extent of movement in each cell substantially increased. Furthermore, the results suggest that mitochondrial mobility is not only a feature observed in proliferative cells but is required for cells to proliferate. To examine this, mitochondrial mobility was reduced using the fission inhibitor Mdivi-1, which, by inhibiting fission, resulted in larger mitochondria and networks with decreased mobility. Mdivi-1 inhibited vascular smooth muscle proliferation. We believe this to be the first direct demonstration of 
mitochondrial mobility in an intact organ in real time in the cardiovascular system and to our knowledge in any tissue other than neurons. It is tempting to speculate that the mitochondrial movements are required to facilitate distribution of mitochondria to daughter cells during division.

Although changes in mitochondrial mobility have not been previously reported during cell proliferation, changes in mitochondrial architecture during the cell cycle have been observed $^{63,64}$ as a result of fission and fusion events. The mitochondria fission inhibitor Mdivi-1 was used in the present study to reduce mitochondrial dynamics rather than to study the role of fission and dynamin-related protein per se. Nonetheless, the results with Mdivi-1 (ie, reduced proliferation) may also suggest that mitochondrial fission (as well as mitochondrial dynamics) is required for cell division to occur. Mitochondrial fission has been linked to preventing and promoting each of autophagy ${ }^{24}$ and apoptosis, ${ }^{28,31,32}$ and the role of mitochondrial fission in cell division is also uncertain. For example, in HeLa cells mitochondria existed as elongated structures and inter-connected networks, and a dynaminrelated protein-mediated fission of the organelle occurred in early mitosis. ${ }^{65}$ In yeast, filamentous mitochondria are distributed to the daughter buds at mitosis. ${ }^{66,67}$ However prevention of mitochondrial fission by inhibiting the function of dynamin-related protein (HeLa cells) ${ }^{65}$ or homolog (Dnm1, yeast ${ }^{66,67}$ did not prevent mitosis from occurring. ${ }^{68}$ On the other hand, in a recent study, ${ }^{69}$ inhibiting dynamin-related protein function (using Mdivi-1 or small interfering RNA) blocked cell cycle progression and reduced cell proliferation rates in cells cultured from human pulmonary artery, suggesting that mitochondrial fission is required for proliferation to occur.

There are several phases to cell cycle progression during proliferation. Progression may include a quiescent phase in which the cells are not dividing (G0), a long growth phase (G1), a DNA replicating phase (S), a short growth phase (G2), and cell division (M). The transition in cell cycle from G1 to S phases can be modulated by the metabolic status of the cell, ${ }^{70}$ and mitochondrial dysfunction activates at least 2 signals that impose a G1 to $\mathrm{S}$ transition checkpoint. ${ }^{71}$ In keeping with these observations, in the present study, inhibiting dynamin-related protein oligomerization with Mdivi-1 significantly decreased the fraction of cells in the $\mathrm{S}$ and increased those in the G0/G1 phase. These results suggest that altering mitochondrial dynamics prevents cell cycle progression to the $\mathrm{S}$ phase. However, in a previous study ${ }^{69}$ Mdivi-1 and small interfering RNA directed against dynamin-related protein resulted in G2/M phase enrichment. Differences in the time course of the experiments and concentrations of Mdivi-1 may explain differences in results. Short (4 hours) inhibition of dynamin-related protein drives cells from G0 to $S$ in the absence of growth factors. ${ }^{63}$ However, prolonged (48 hours) inhibition (as in the present study) inhibits S-phase entry. ${ }^{63}$ Differences in the concentration of Mdivi-1 used in the present $(10 \mu \mathrm{mol} / \mathrm{L})$ and previous $(25 \mu \mathrm{mol} / \mathrm{L})^{69}$ study may also contribute to the differences in results. Although Mdivi-1 $(25 \mu \mathrm{mol} / \mathrm{L})$ increased the fraction of cells in the G2/M phase, ${ }^{69}$ in the same study, Mdivi-1 (10 $\mu \mathrm{mol} / \mathrm{L}$, used in the present study) did not increase the fraction of cells in the G2/M stage.

The present study has highlighted the adaptability of mitochondria and the occurrence of mitochondrial dynamics under physiological conditions. Hitherto, in the cardiovascular system, and especially in native cells, relatively little was known about the function mitochondrial movement performs. In various cardiac immortalized cell lines and neonatal cells, mitochondria are highly dynamic organelles that continuously move and change their shape. However, in native cell types, the significance and very occurrence of mitochondrial movement are questioned. ${ }^{13}$ For example, in cardiac myocytes only a restricted Brownian motion but no large-scale movement was detected. ${ }^{16}$ Several studies have shown that mitochondria in adult cardiomyocytes behave as distinct entities, are arranged in a 
longitudinal lattice between the myofibrils, do not form reticular networks, and show no evidence for fusion or fission. ${ }^{16,40}$ Although not directly visualized, it is nonetheless believed that some type of mitochondrial dynamics may occur in adult heart, smooth muscle, and endothelial cells. This conclusion is derived from observations that various treatments (eg, coronary ligation, ${ }^{72}$ ischemia-reperfusion injury, ${ }^{58,73}$ pulmonary hypertension, ${ }^{69}$ diabetes mellitus) ${ }^{74}$ may produce unusually large or small mitochondria. ${ }^{75}$ These results suggest that mitochondria, at least in cases of extreme stress, are not entirely static and can undergo dynamics in the form of fission or fusion. There are physiological consequences to these fission and fusion events. Treatment with the mitochondrial fission inhibitor Mdivi-1 inhibited opening of the permeability transition pore to reduce cardiomyocyte cell death after ischemia-reperfusion and reduced myocardial infarct size in vivo in mice subjected to coronary artery occlusion. ${ }^{58}$ Mdivi-1 also reduced tubular cell apoptosis and kidney damage during renal ischemia-reperfusion injury. ${ }^{73}$ In pulmonary hypertension, electron microscopy measurements revealed that mitochondria appeared smaller than those in control pulmonary artery smooth muscle, suggesting the organelle undergoes fission in disease. ${ }^{69}$ Significantly, inhibiting dynamin-related protein (with Mdivi-1) restored mitochondrial size and exhibited antiproliferative effects by reducing the muscularization of small pulmonary arteries (consistent with an antiproliferative effect) in pulmonary hypertensive animals. This effect decreased pulmonary vascular resistance and right ventricular hypertrophy and increased exercise capacity. ${ }^{69}$ Together, these results suggest that reducing mitochondrial fission can limit cardiovascular damage and raise the possibility that manipulating mitochondrial dynamics may be protective in cardiovascular disease.

The organization of mitochondria in native smooth muscle is ill-defined. In the present study, there was no obvious repeating pattern to the organization as occurs in cardiac myocytes, and mitochondria appeared approximately randomly and uniformly distributed through the cytoplasm. ${ }^{12,76}$ In electron micrograph studies, mitochondria in smooth muscle were distributed throughout the cytoplasm and closely associated (and ensheathed) with sarcoplasmic reticulum. ${ }^{77}$ Mitochondria in the majority of native smooth muscle cells do not show dynamic behavior, raising the question why mitochondria are immobile in native cells. Mitochondria may have been tethered by the cytoskeleton. However, disruption with nocodazole did not increase mitochondrial motility. Increases in $\left[\mathrm{Ca}^{2+}\right]_{\mathrm{c}}$ are also known to inhibit motility. ${ }^{50}$ Perhaps an elevated $\left[\mathrm{Ca}^{2+}\right]_{\mathrm{c}}$ in the native cells (compared with proliferative cells) explained the lack of motility. However, a $\mathrm{Ca}^{2+}$-free bathing solution did not increase mitochondrial dynamics in the native cells. Mitochondria may be held in place by tethering in native smooth muscle cells and possibly to the sarcoplasmic reticulum ${ }^{77}$.

In the present study, a fundamental, previously unrecognized, feature of vascular smooth muscle proliferation (ie, a change in mitochondrial architecture and increase in mobility) has been described, and the results show real-time mitochondrial movement for the first time in intact tissue. Significantly, the increase in mitochondrial dynamics substantially precedes the increase in smooth muscle proliferation. We propose that increased mitochondrial movement is required to support the proliferative state in adult vascular smooth muscle. The poorly understood interactions between mitochondrial dynamics and physiological function are complex and likely to provide significant targets for clinical medicine. Smooth muscle proliferation is a hallmark of vascular disease, and mitochondrial movement may present a target for therapies to limit changes in the artery wall in proliferative vascular disease.

\section{Supplementary Material}

Refer to Web version on PubMed Central for supplementary material. 


\section{Acknowledgments}

We are grateful to Dr Tony McCloskey and Mark McAskill for useful discussions on fluorescence-activated cell sorter protocols and Dr Stuart Cochrane for advice on ${ }^{3} \mathrm{H}$-thymidine uptake experiments and Drs Marnie Olson and Mairi Sandison for comments on the manuscript.

Sources of Funding: This work was funded by the Wellcome Trust (092292/Z/10/Z), British Heart Foundation (PG/11/70/29086 and research excellence award) and the Engineering and Physical Sciences Research Council; their support is gratefully acknowledged.

\section{References}

1. Ross R. Atherosclerosis-an inflammatory disease. N Engl J Med. 1999; 340:115-126. [PubMed: 9887164]

2. Weintraub WS. The pathophysiology and burden of restenosis. Am J Cardiol. 2007; 100:3K-9K.

3. Orr AW, Hastings NE, Blackman BR, Wamhoff BR. Complex regulation and function of the inflammatory smooth muscle cell phenotype in atherosclerosis. J Vasc Res. 2010; 47:168-180. [PubMed: 19851078]

4. Zargham R. Preventing restenosis after angioplasty: a multistage approach. Clin Sci. 2008; 114:257-264. [PubMed: 18194134]

5. Hajnóczky G, Hager R, Thomas AP. Mitochondria suppress local feedback activation of inositol 1,4, 5-trisphosphate receptors by $\mathrm{Ca}^{2+} \mathrm{J}$ Biol Chem. 1999; 274:14157-14162. [PubMed: 10318833]

6. Narayanan D, Xi Q, Pfeffer LM, Jaggar JH. Mitochondria control functional CaV1.2 expression in smooth muscle cells of cerebral arteries. Circ Res. 2010; 107:631-641. [PubMed: 20616314]

7. Saunter CD, Perng MD, Love GD, Quinlan RA. Stochastically determined directed movement explains the dominant small-scale mitochondrial movements within non-neuronal tissue culture cells. FEBS Lett. 2009; 583:1267-1273. [PubMed: 19265695]

8. Miller KE, Sheetz MP. Direct evidence for coherent low velocity axonal transport of mitochondria. J Cell Biol. 2006; 173:373-381. [PubMed: 16682527]

9. Miller KE, Sheetz MP. Axonal mitochondrial transport and potential are correlated. J Cell Sci. 2004; 117(Pt 13):2791-2804. [PubMed: 15150321]

10. Benard G, Bellance N, James D, Parrone P, Fernandez H, Letellier T, Rossignol R. Mitochondrial bioenergetics and structural network organization. J Cell Sci. 2007; 120(Pt 5):838-848. [PubMed: 17298981]

11. Chalmers S, McCarron JG. The mitochondrial membrane potential and $\mathrm{Ca}^{2+}$ oscillations in smooth muscle. J Cell Sci. 2008; 121(Pt 1):75-85. [PubMed: 18073239]

12. O'Reilly CM, Fogarty KE, Drummond RM, Tuft RA, Walsh JV Jr. Spontaneous mitochondrial depolarizations are independent of SR $\mathrm{Ca}^{2+}$ release. Am J Physiol, Cell Physiol. 2004; 286:C1139-C1151. [PubMed: 15075213]

13. Das S, Hajnóczky N, Antony AN, Csordás G, Gaspers LD, Clemens DL, Hoek JB, Hajnóczky G. Mitochondrial morphology and dynamics in hepatocytes from normal and ethanol-fed rats. Pflugers Arch. 2012; 464:101-109. [PubMed: 22526459]

14. Park MK, Ashby MC, Erdemli G, Petersen OH, Tepikin AV. Perinuclear, perigranular and subplasmalemmal mitochondria have distinct functions in the regulation of cellular calcium transport. EMBO J. 2001; 20:1863-1874. [PubMed: 11296220]

15. Molina AJ, Wikstrom JD, Stiles L, Las G, Mohamed H, Elorza A, Walzer G, Twig G, Katz S, Corkey BE, Shirihai OS. Mitochondrial networking protects beta-cells from nutrient-induced apoptosis. Diabetes. 2009; 58:2303-2315. [PubMed: 19581419]

16. Beraud N, Pelloux S, Usson Y, Kuznetsov AV, Ronot X, Tourneur Y, Saks V. Mitochondrial dynamics in heart cells: very low amplitude high frequency fluctuations in adult cardiomyocytes and flow motion in non beating Hl-1 cells. J Bioenerg Biomembr. 2009; 41:195-214. [PubMed: 19399598]

17. Hom J, Sheu SS. Morphological dynamics of mitochondria-a special emphasis on cardiac muscle cells. J Mol Cell Cardiol. 2009; 46:811-820. [PubMed: 19281816] 
18. Davis AF, Clayton DA. In situ localization of mitochondrial DNA replication in intact mammalian cells. J Cell Biol. 1996; 135:883-893. [PubMed: 8922374]

19. Hollenbeck PJ. The pattern and mechanism of mitochondrial transport in axons. Front Biosci. 1996; 1:d91-102. [PubMed: 9159217]

20. Hollenbeck PJ, Saxton WM. The axonal transport of mitochondria. J Cell Sci. 2005; 118(Pt 23): 5411-5419. [PubMed: 16306220]

21. MacAskill AF, Kittler JT. Control of mitochondrial transport and localization in neurons. Trends Cell Biol. 2010; 20:102-112. [PubMed: 20006503]

22. Yi M, Weaver D, Hajnóczky G. Control of mitochondrial motility and distribution by the calcium signal: a homeostatic circuit. J Cell Biol. 2004; 167:661-672. [PubMed: 15545319]

23. Rintoul GL, Filiano AJ, Brocard JB, Kress GJ, Reynolds IJ. Glutamate decreases mitochondrial size and movement in primary forebrain neurons. J Neurosci. 2003; 23:7881-7888. [PubMed: 12944518]

24. Brough D, Schell MJ, Irvine RF. Agonist-induced regulation of mitochondrial and endoplasmic reticulum motility. Biochem J. 2005; 392(Pt 2):291-297. [PubMed: 15982187]

25. Wang X, Schwarz TL. The mechanism of $\mathrm{Ca}^{2+}$-dependent regulation of kinesin-mediated mitochondrial motility. Cell. 2009; 136:163-174. [PubMed: 19135897]

26. Pilling AD, Horiuchi D, Lively CM, Saxton WM. Kinesin-1 and Dynein are the primary motors for fast transport of mitochondria in Drosophila motor axons. Mol Biol Cell. 2006; 17:2057-2068. [PubMed: 16467387]

27. Kerschensteiner M, Reuter MS, Lichtman JW, Misgeld T. Ex vivo imaging of motor axon dynamics in murine triangularis sterni explants. Nat Protoc. 2008; 3:1645-1653. [PubMed: 18833201]

28. Twig G, Elorza A, Molina AJ, et al. Fission and selective fusion govern mitochondrial segregation and elimination by autophagy. EMBO J. 2008; 27:433-446. [PubMed: 18200046]

29. Parone PA, Da Cruz S, Tondera D, Mattenberger Y, James DI, Maechler P, Barja F, Martinou JC. Preventing mitochondrial fission impairs mitochondrial function and leads to loss of mitochondrial DNA. PLoS ONE. 2008; 3:e3257. [PubMed: 18806874]

30. Chen H, Chomyn A, Chan DC. Disruption of fusion results in mitochondrial heterogeneity and dysfunction. J Biol Chem. 2005; 280:26185-26192. [PubMed: 15899901]

31. Karbowski M. Mitochondria on guard: role of mitochondrial fusion and fission in the regulation of apoptosis. Adv Exp Med Biol. 2010; 687:131-142. [PubMed: 20919642]

32. Frank S, Gaume B, Bergmann-Leitner ES, Leitner WW, Robert EG, Catez F, Smith CL, Youle RJ. The role of dynamin-related protein 1, a mediator of mitochondrial fission, in apoptosis. Dev Cell. 2001; 1:515-525. [PubMed: 11703942]

33. James DI, Martinou JC. Mitochondrial dynamics and apoptosis: a painful separation. Dev Cell. 2008; 15:341-343. [PubMed: 18804432]

34. Perfettini JL, Roumier T, Kroemer G. Mitochondrial fusion and fission in the control of apoptosis. Trends Cell Biol. 2005; 15:179-183. [PubMed: 15817372]

35. Szabadkai G, Simoni AM, Chami M, Wieckowski MR, Youle RJ, Rizzuto R. Drp-1-dependent division of the mitochondrial network blocks intraorganellar $\mathrm{Ca}^{2+}$ waves and protects against $\mathrm{Ca}^{2+}$-mediated apoptosis. Mol Cell. 2004; 16:59-68. [PubMed: 15469822]

36. Chalmers S, Caldwell ST, Quin C, Prime TA, James AM, Cairns AG, Murphy MP, McCarron JG, Hartley RC. Selective uncoupling of individual mitochondria within a cell using a mitochondriatargeted photoactivated protonophore. J Am Chem Soc. 2012; 134:758-761. [PubMed: 22239373]

37. McCarron JG, Olson ML, Currie S, Wright AJ, Anderson KI, Girkin JM. Elevations of intracellular calcium reflect normal voltage-dependent behavior, and not constitutive activity, of voltage-dependent calcium channels in gastrointestinal and vascular smooth muscle. J Gen Physiol. 2009; 133:439-457. [PubMed: 19289573]

38. Saunter CD. Quantifying subpixel accuracy: an experimental method for measuring accuracy in image-correlation-based, single-particle tracking. Biophys J. 2010; 98:1566-1570. [PubMed: 20409476]

39. Lazzarino DA, Boldogh I, Smith MG, Rosand J, Pon LA. Yeast mitochondria contain ATPsensitive, reversible actin-binding activity. Mol Biol Cell. 1994; 5:807-818. [PubMed: 7812049] 
40. Vendelin M, Béraud N, Guerrero K, Andrienko T, Kuznetsov AV, Olivares J, Kay L, Saks VA. Mitochondrial regular arrangement in muscle cells: a "crystal-like" pattern. Am J Physiol, Cell Physiol. 2005; 288:C757-C767. [PubMed: 15496480]

41. Aon MA, Cortassa S, O'Rourke B. Percolation and criticality in a mitochondrial network. Proc Natl Acad Sci USA. 2004; 101:4447-4452. [PubMed: 15070738]

42. Ball EH, Singer SJ. Mitochondria are associated with microtubules and not with intermediate filaments in cultured fibroblasts. Proc Natl Acad Sci USA. 1982; 79:123-126. [PubMed: 6275382]

43. Heggeness MH, Simon M, Singer SJ. Association of mitochondria with microtubules in cultured cells. Proc Natl Acad Sci USA. 1978; 75:3863-3866. [PubMed: 80800]

44. Smith MG, Simon VR, O’Sullivan H, Pon LA. Organelle-cytoskeletal interactions: actin mutations inhibit meiosis-dependent mitochondrial rearrangement in the budding yeast Saccharomyces cerevisiae. Mol Biol Cell. 1995; 6:1381-1396. [PubMed: 8573793]

45. Goldstein LS, Yang Z. Microtubule-based transport systems in neurons: the roles of kinesins and dyneins. Annu Rev Neurosci. 2000; 23:39-71. [PubMed: 10845058]

46. Svoboda K, Schmidt CF, Schnapp BJ, Block SM. Direct observation of kinesin stepping by optical trapping interferometry. Nature. 1993; 365:721-727. [PubMed: 8413650]

47. Mallik R, Carter BC, Lex SA, King SJ, Gross SP. Cytoplasmic dynein functions as a gear in response to load. Nature. 2004; 427:649-652. [PubMed: 14961123]

48. Gross SP, Vershinin M, Shubeita GT. Cargo transport: two motors are sometimes better than one. Curr Biol. 2007; 17:R478-R486. [PubMed: 17580082]

49. Hancock WO. Intracellular transport: kinesins working together. Curr Biol. 2008; 18:R715-R717. [PubMed: 18727910]

50. Saotome M, Safiulina D, Szabadkai G, Das S, Fransson A, Aspenstrom P, Rizzuto R, Hajnóczky G. Bidirectional $\mathrm{Ca}^{2+}$-dependent control of mitochondrial dynamics by the Miro GTPase. Proc Natl Acad Sci USA. 2008; 105:20728-20733. [PubMed: 19098100]

51. Verbrugge S, Kapitein LC, Peterman EJ. Kinesin moving through the spotlight: single-motor fluorescence microscopy with submillisecond time resolution. Biophys J. 2007; 92:2536-2545. [PubMed: 17237204]

52. Davis MJ, Hill MA. Signaling mechanisms underlying the vascular myogenic response. Physiol Rev. 1999; 79:387-423. [PubMed: 10221985]

53. Rzucidlo EM, Martin KA, Powell RJ. Regulation of vascular smooth muscle cell differentiation. J Vasc Surg. 2007; 45(Suppl A):A25-A32. [PubMed: 17544021]

54. Owens GK, Kumar MS, Wamhoff BR. Molecular regulation of vascular smooth muscle cell differentiation in development and disease. Physiol Rev. 2004; 84:767-801. [PubMed: 15269336]

55. Nunnari J, Marshall WF, Straight A, Murray A, Sedat JW, Walter P. Mitochondrial transmission during mating in Saccharomyces cerevisiae is determined by mitochondrial fusion and fission and the intramitochondrial segregation of mitochondrial DNA. Mol Biol Cell. 1997; 8:1233-1242. [PubMed: 9243504]

56. Cassidy-Stone A, Chipuk JE, Ingerman E, Song C, Yoo C, Kuwana T, Kurth MJ, Shaw JT, Hinshaw JE, Green DR, Nunnari J. Chemical inhibition of the mitochondrial division dynamin reveals its role in Bax/Bak-dependent mitochondrial outer membrane permeabilization. Dev Cell. 2008; 14:193-204. [PubMed: 18267088]

57. Duchen MR, Leyssens A, Crompton M. Transient mitochondrial depolarizations reflect focal sarcoplasmic reticular calcium release in single rat cardiomyocytes. J Cell Biol. 1998; 142:975988. [PubMed: 9722610]

58. Ong SB, Subrayan S, Lim SY, Yellon DM, Davidson SM, Hausenloy DJ. Inhibiting mitochondrial fission protects the heart against ischemia/reperfusion injury. Circulation. 2010; 121:2012-2022. [PubMed: 20421521]

59. So EC, Hsing CH, Liang CH, Wu SN. The actions of mdivi-1, an inhibitor of mitochondrial fission, on rapidly activating delayed-rectifier K? current and membrane potential in HL-1 murine atrial cardiomyocytes. Eur J Pharmacol. 2012; 683:1-9. [PubMed: 22374256]

60. Cidad P, Moreno-Domínguez A, Novensá L, Roqué M, Barquín L, Heras M, Pérez-García MT, López-López JR. Characterization of ion channels involved in the proliferative response of 
femoral artery smooth muscle cells. Arterioscler Thromb Vasc Biol. 2010; 30:1203-1211. [PubMed: 20299686]

61. Cidad P, Jiménez-Pérez L, García-Arribas D, Miguel-Velado E, Tajada S, Ruiz-McDavitt C, López-López JR, Pérez-García MT. Kv1.3 channels can modulate cell proliferation during phenotypic switch by an ion-flux independent mechanism. Arterioscler Thromb Vasc Biol. 2012; 32:1299-1307. [PubMed: 22383699]

62. Zhuge R, Fogarty KE, Baker SP, McCarron JG, Tuft RA, Lifshitz LM, Walsh JV Jr. Ca ${ }^{2+}$ ) spark sites in smooth muscle cells are numerous and differ in number of ryanodine receptors, largeconductance $\mathrm{K}(+)$ channels, and coupling ratio between them. Am J Physiol, Cell Physiol. 2004; 287:C1577-C1588. [PubMed: 15306542]

63. Mitra K, Wunder C, Roysam B, Lin G, Lippincott-Schwartz J. A hyperfused mitochondrial state achieved at G1-S regulates cyclin E buildup and entry into S phase. Proc Natl Acad Sci USA. 2009; 106:11960-11965. [PubMed: 19617534]

64. Kashatus DF, Lim KH, Brady DC, Pershing NL, Cox AD, Counter CM. RALA and RALBP1 regulate mitochondrial fission at mitosis. Nat Cell Biol. 2011; 13:1108-1115. [PubMed: 21822277]

65. Taguchi N, Ishihara N, Jofuku A, Oka T, Mihara K. Mitotic phosphorylation of dynamin-related GTPase Drp1 participates in mitochondrial fission. J Biol Chem. 2007; 282:11521-11529. [PubMed: 17301055]

66. Otsuga D, Keegan BR, Brisch E, Thatcher JW, Hermann GJ, Bleazard W, Shaw JM. The dynaminrelated GTPase, Dnm1p, controls mitochondrial morphology in yeast. J Cell Biol. 1998; 143:333349. [PubMed: 9786946]

67. Bleazard W, McCaffery JM, King EJ, Bale S, Mozdy A, Tieu Q, Nunnari J, Shaw JM. The dynamin-related GTPase Dnm1 regulates mitochondrial fission in yeast. Nat Cell Biol. 1999; 1:298-304. [PubMed: 10559943]

68. Horn SR, Thomenius MJ, Johnson ES, Freel CD, Wu JQ, Coloff JL, Yang CS, Tang W, An J, Ilkayeva OR, Rathmell JC, Newgard CB, Kornbluth S. Regulation of mitochondrial morphology by APC/CCdh1-mediated control of Drp1 stability. Mol Biol Cell. 2011; 22:1207-1216. [PubMed: 21325626]

69. Marsboom G, Toth PT, Ryan JJ, Hong Z, Wu X, Fang YH, Thenappan T, Piao L, Zhang HJ, Pogoriler J, Chen Y, Morrow E, Weir EK, Rehman J, Archer SL. Dynamin-related protein 1mediated mitochondrial mitotic fission permits hyperproliferation of vascular smooth muscle cells and offers a novel therapeutic target in pulmonary hypertension. Circ Res. 2012; 110:1484-1497. [PubMed: 22511751]

70. Mandal S, Freije WA, Guptan P, Banerjee U. Metabolic control of G1-S transition: cyclin E degradation by p53-induced activation of the ubiquitin-proteasome system. J Cell Biol. 2010; 188:473-479. [PubMed: 20176921]

71. Owusu-Ansah E, Yavari A, Mandal S, Banerjee U. Distinct mitochondrial retrograde signals control the G1-S cell cycle checkpoint. Nat Genet. 2008; 40:356-361. [PubMed: 18246068]

72. Chen L, Gong Q, Stice JP, Knowlton AA. Mitochondrial OPA1, apoptosis, and heart failure. Cardiovasc Res. 2009; 84:91-99. [PubMed: 19493956]

73. Brooks C, Wei Q, Cho SG, Dong Z. Regulation of mitochondrial dynamics in acute kidney injury in cell culture and rodent models. J Clin Invest. 2009; 119:1275-1285. [PubMed: 19349686]

74. Shenouda SM, Widlansky ME, Chen K, et al. Altered mitochondrial dynamics contributes to endothelial dysfunction in diabetes mellitus. Circulation. 2011; 124:444-453. [PubMed: 21747057]

75. Hom J, Yu T, Yoon Y, Porter G, Sheu SS. Regulation of mitochondrial fission by intracellular $\mathrm{Ca}^{2+}$ in rat ventricular myocytes. Biochim Biophys Acta. 2010; 1797:913-921. [PubMed: 20347716]

76. Drummond RM, Mix TC, Tuft RA, Walsh JV Jr, Fay FS. Mitochondrial $\mathrm{Ca}^{2+}$ homeostasis during $\mathrm{Ca}^{2+}$ influx and $\mathrm{Ca}^{2+}$ release in gastric myocytes from Bufo marinus. J Physiol. 2000; 522(Pt 3): 375-390. [PubMed: 10713963] 
77. Nixon GF, Mignery GA, Somlyo AV. Immunogold localization of inositol 1,4,5-trisphosphate receptors and characterization of ultrastructural features of the sarcoplasmic reticulum in phasic and tonic smooth muscle. J Muscle Res Cell Motil. 1994; 15:682-700. [PubMed: 7706424] 

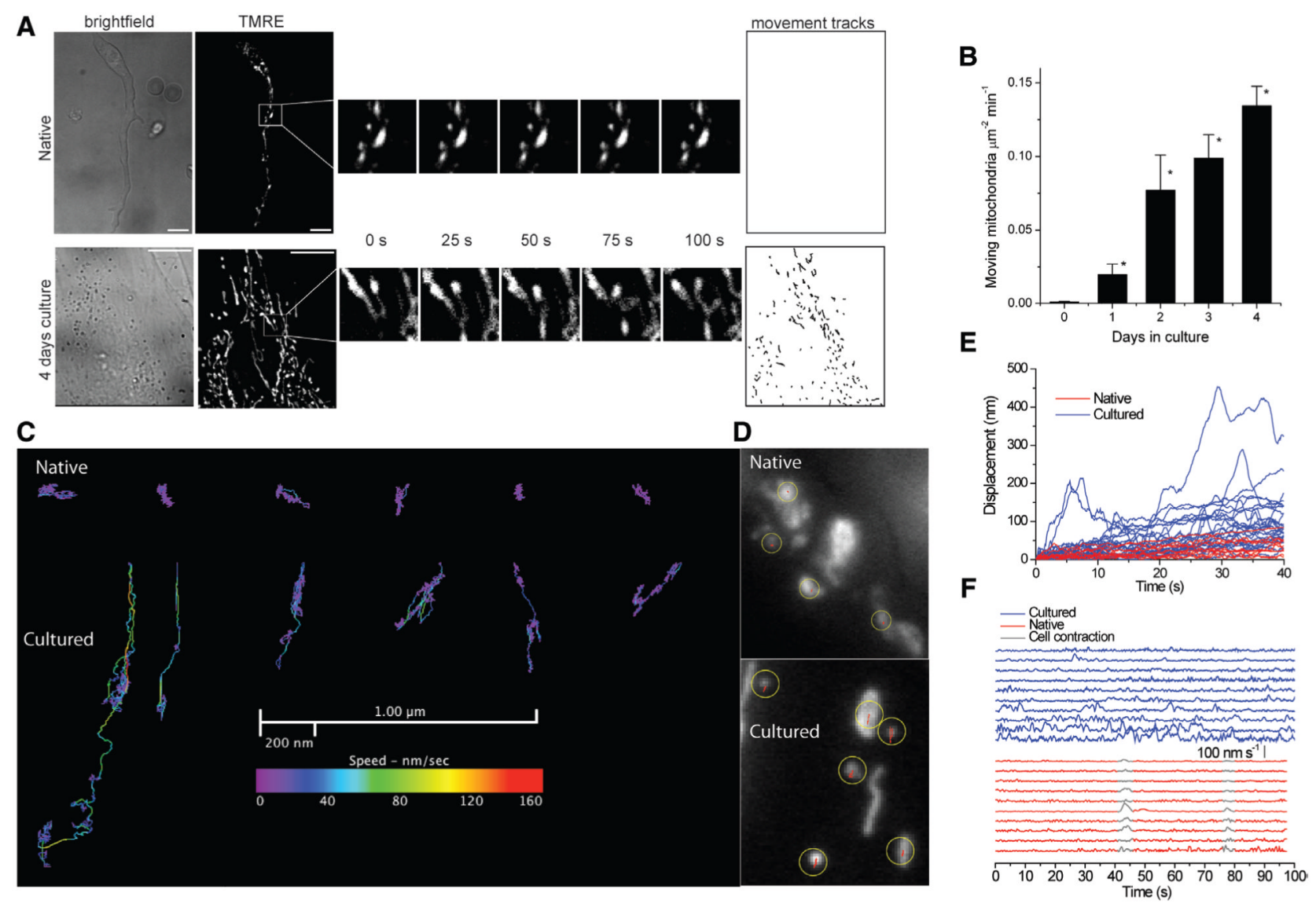

Figure 1. Mitochondria are largely immobile in native cells and highly dynamic in cultured cerebral resistance artery smooth muscle cells.

A, Native (freshly isolated) smooth muscle cells display very little mitochondrial motility (top). After 4 days in culture (bottom), the organization of mitochondria changed significantly and the organelles became highly mobile, showing a wide variety of dynamic behavior that included Brownian-like motion and directed movements (scale bars in top and bottom, $10 \mu \mathrm{m})$. Movement tracks for the native and cultured cells are shown in the boxes in right; no movement occurred in the native cell, whereas the cultured cell had extensive movement. Tracks of mitochondrial movement (right) are dilated by 2 pixels to aid visualization. B, The total number of mitochondria moving per minute were counted and corrected for mitochondrial area within each cell; the histogram shows mean $\pm \mathrm{SE}$ for $\mathrm{n} \otimes$ cells from at least 3 independent cell isolations ( $* P<0.001$ each cf. control, day 0$)$. The data shown in $\mathbf{B}$ were from tetramethylrhodamine ethyl ester (TMRE)-loaded cells; in a separate series of experiments, cells were loaded with MitoTracker green, and essentially identical results were obtained ( $\mathrm{n} \geq 5$ cells for each day). C, Motion tracks of the 6 most motile mitochondria from the native cells (top) are compared with the least motile mitochondria in cultured cells (bottom). The plot shows the $x$ - $y$ displacement and velocities of each mitochondrion. Mitochondria in native cells show almost no movement, whereas those in cultured cells engage in brief bursts of motion at speeds of $\approx 160 \mathrm{~nm} / \mathrm{s}$, resulting in substantial movement of the organelle. D, To provide a sense of scale of the movement, the motion tracks (in red) are overlaid on the mitochondria images. The yellow circles show the position of the mitochondria's center in the first frame of the sequence. The red motion tracks on the mitochondria of the native cells are $\approx 1$ pixel and so difficult to visualize. Some mitochondria were not tracked, for example, because they are closely packed to be 
accurately separated by the software. E, The displacement of the tracked mitochondria plotted as a function of time. Displacement is defined as the distance between the position of an organelle at time $t$ and at time 0 . Mitochondria in cultured cells (blue) undergo bursts of motion that cover large distances compared with the displacement of mitochondria within the native cells (red). F, The instantaneous speed of the mitochondria measured by comparing the organelles' position during 1-second intervals. The speeds for the mitochondria tracked within the native (red) and cultured (blue) cells are plotted. The speeds have been separated in the vertical axis for clarity. Apart from 2 global motion events caused by slight contraction of the entire cell (shown in gray), the mitochondria in the native cell are inactive. In the cultured cell, many bursts of high-speed motion occurred with a maximum speed of typically $100 \mathrm{~nm} / \mathrm{s}$. In all experiments, TMRE was used to visualize mitochondria via epifluorescence microscopy, and images were acquired at $10 \mathrm{~Hz}$. 


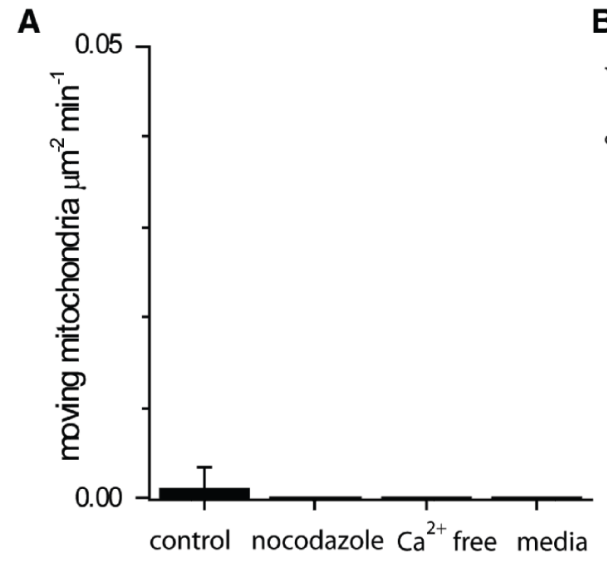

D

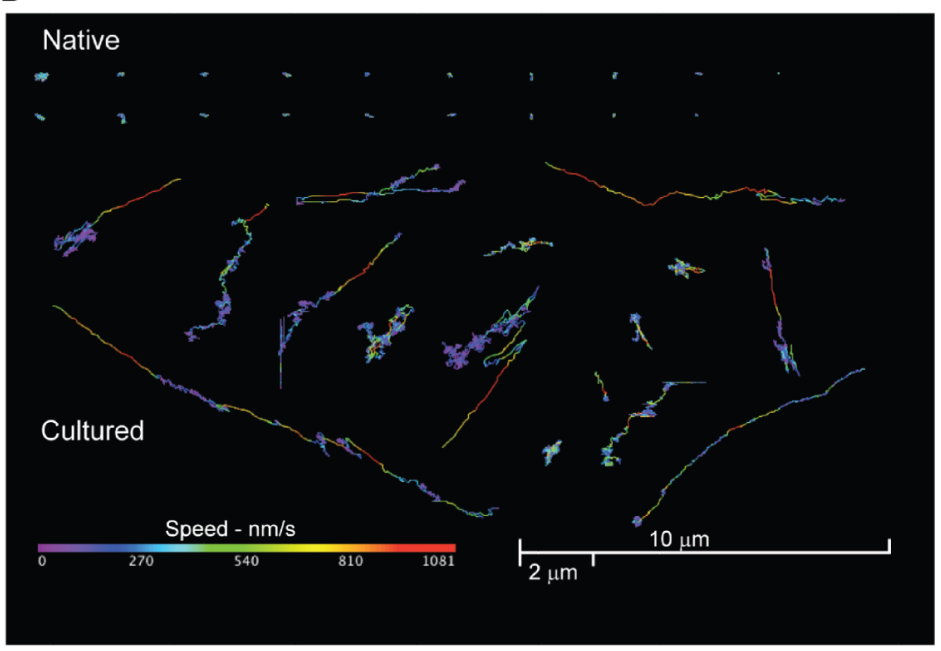

B

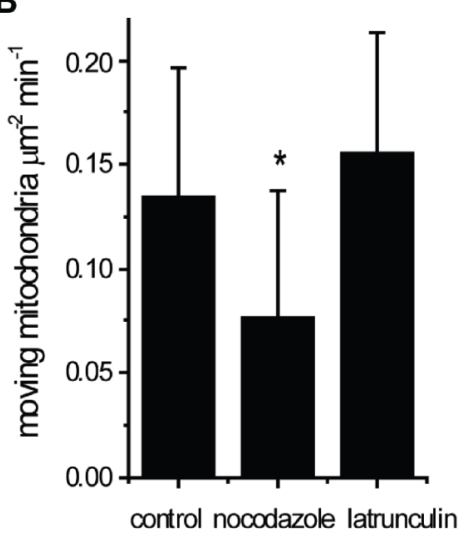

E
C

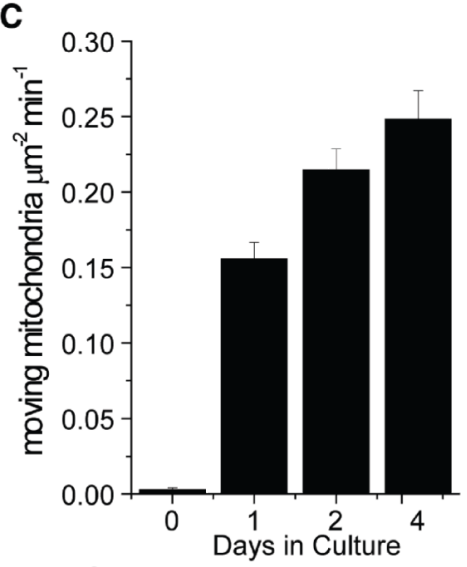

Cultured

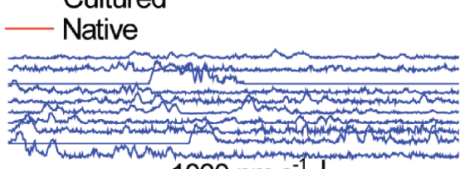

$1000 \mathrm{~nm} \mathrm{~s}^{-1}$
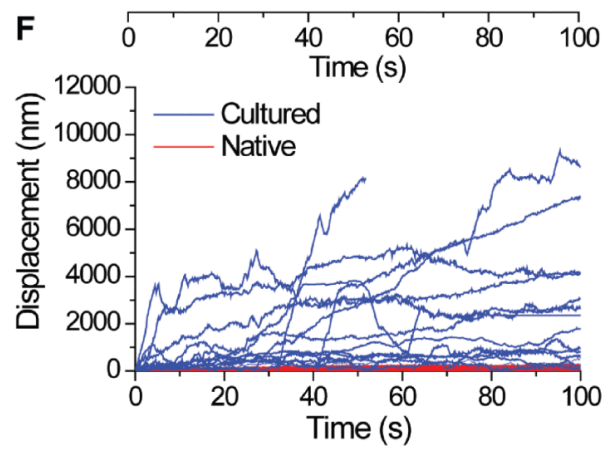

Figure 2. Mitochondrial motility in native and cultured smooth muscle cells.

A, In native cerebral resistance artery smooth muscle cells, neither nocodazole $(10 \mu \mathrm{mol} / \mathrm{L})$ nor replacement of the normal cellular bathing solution with either $\mathrm{Ca}^{2+}$-free solution or cell culture media induced mitochondrial movement. The total number of mitochondria moving per minute were counted and corrected for mitochondrial area within each cell; the histogram shows mean \pm SE for $\mathrm{n} \geq 5$ cells for each treatment $(P>0.05$, nocodazole; $P>0.05$, $\mathrm{Ca}^{2+}$-free; $P>0.05$, media). B, Cerebral resistance artery cells were maintained in culture for 4 days and then incubated with nocodazole $(10 \mu \mathrm{mol} / \mathrm{L})$ or latrunculin B $(10 \mu \mathrm{mol} / \mathrm{L})$. The total number of mitochondria moving per minute were counted and corrected for mitochondrial area within each cell; the histogram shows mean \pm SE for $\mathrm{n} \geq 8$ cells for each treatment $(P<0.05$, nocodazole; $P>0.05$, latrunculin B each cf. control). $* P<0.05$ was considered significant; note the increase in scale compared with Figure $2 \mathrm{~A}$. $\mathbf{C}$, At $37^{\circ} \mathrm{C}$, the total number of mitochondria moving per minute were counted and corrected for mitochondrial area within each cell; the histogram shows mean \pm SE for $n \geq 14$ cells from at least 3 independent cell isolations. D, At $37^{\circ} \mathrm{C}$, the motion tracks from mitochondria from the native cells (top) show essentially no movement (like those at room temperature). Cultured cells (bottom) show wide ranging movement with increased displacement and velocities compared with those measured at room temperature (Figure 1C-1F). The plot shows the $x-y$ displacement and velocities of each mitochondrion. Scale bars for speed and displacement are shown. $\mathbf{E}$, At $37^{\circ} \mathrm{C}$, the instantaneous speed of the mitochondria was 
measured by comparing the organelles' position during 1-second intervals. The speeds for the mitochondria tracked within the native (red) and cultured (blue) cells are plotted. The speeds have been separated in the vertical axis for clarity. The mitochondria of native cells are inactive. In the cultured cell, many bursts of high-speed motion occurred with a maximum speed that was approaching $10 \times$ that measured at room temperature $(1000 \mathrm{~nm} / \mathrm{s})$. $\mathbf{F}$, At $37^{\circ} \mathrm{C}$, the displacement of the tracked mitochondria was plotted as a function of time. Displacement is defined as the distance between the position of an organelle at time $t$ and at time 0 . Mitochondria in cultured cells (blue) undergo bursts of motion that cover large distances compared with the displacement of mitochondria within the native cells (red). Images were acquired at $7.3 \mathrm{~Hz}$. 

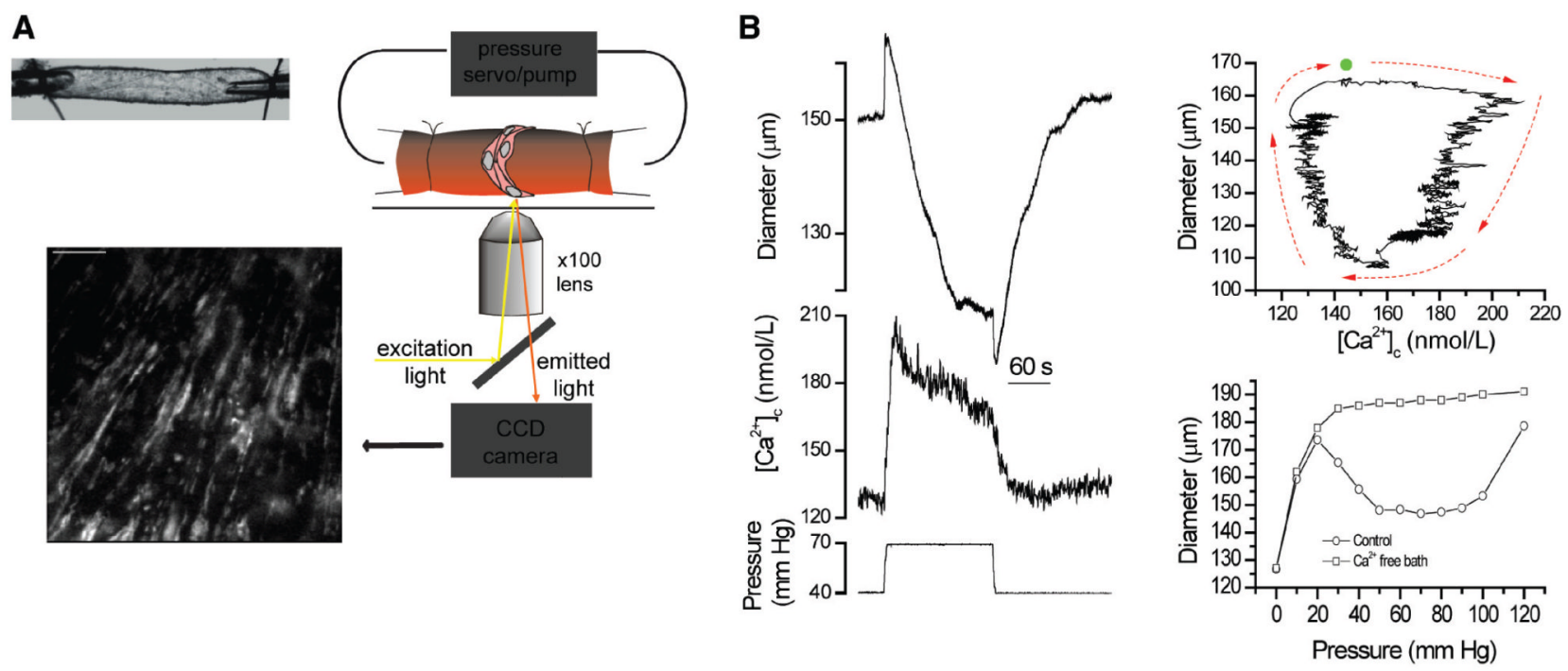

Figure 3. Mitochondria were imaged in intact resistance arteries that show myogenic tone at physiological pressures.

A, Second-order branches of the posterior cerebral resistance artery were cannulated, maintained at physiological pressure $(40 \mathrm{~mm} \mathrm{Hg})$, and incubated with tetramethylrhodamine ethyl ester to visualize mitochondria within the lower-most face of the intact vessel by epifluorescence microscopy. Scale bar, $10 \mu \mathrm{m}$. B, Cannulated resistance arteries maintain myogenic tone, contracting in response to elevated intraluminal pressure with a concurrent rise in intracellular $\left[\mathrm{Ca}^{2+}\right]_{\mathrm{c}}$ that is maintained for the duration of pressure elevation. CCD indicates charge-coupled device. 
A
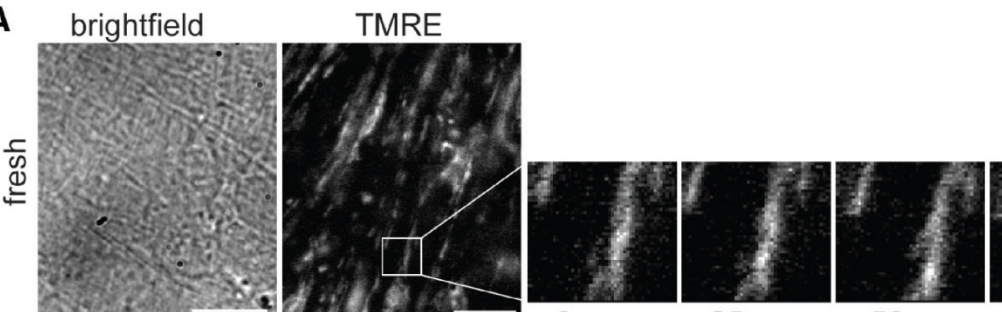

movement tracks

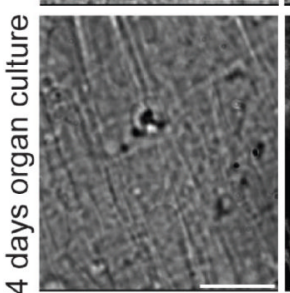

$0 \mathrm{~s}$ $25 \mathrm{~s}$ $50 \mathrm{~s}$
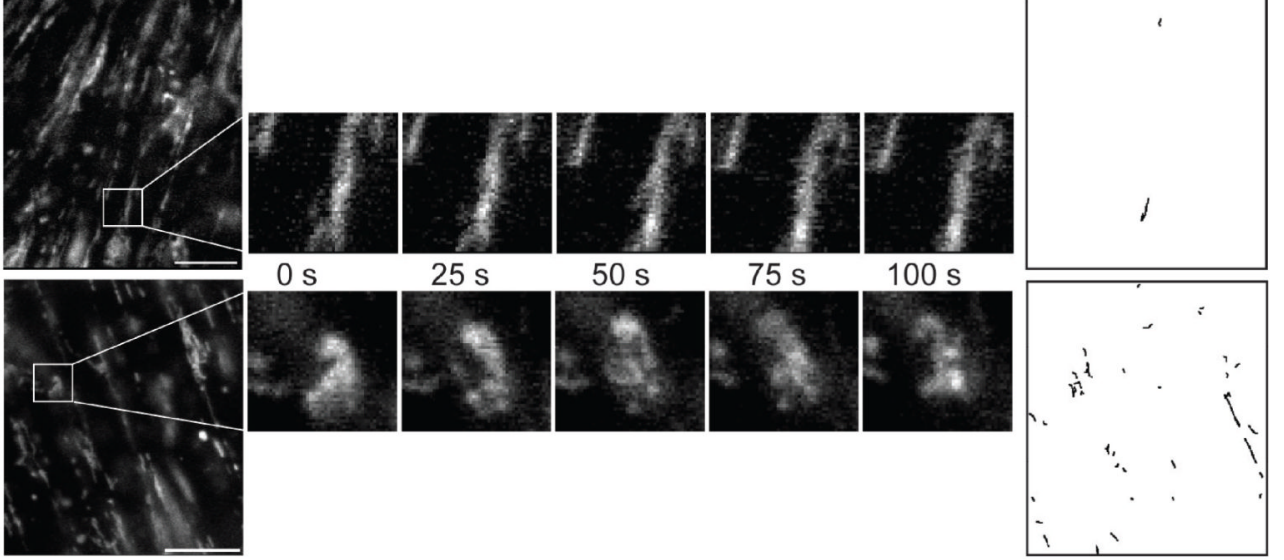

B
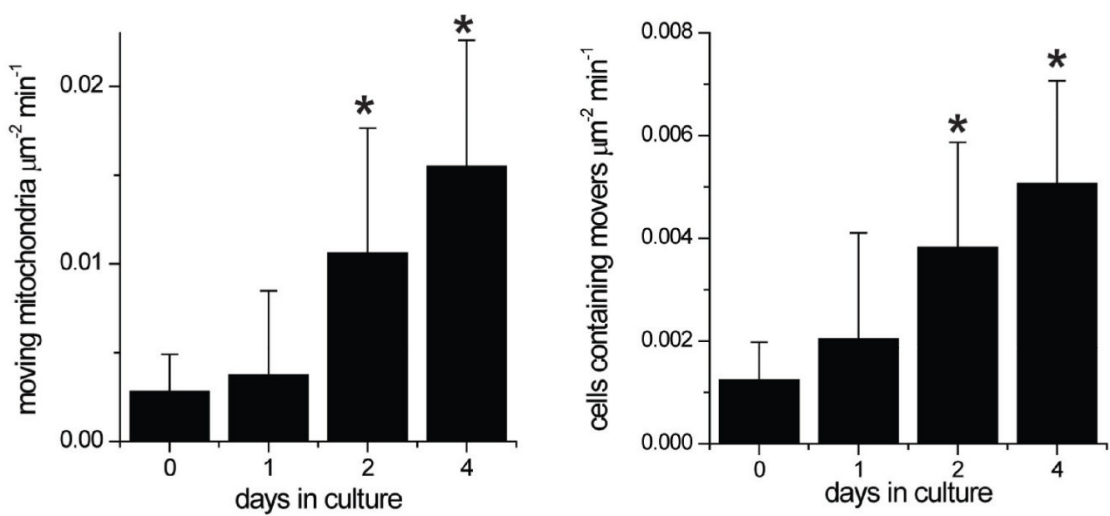

C

Culture: $0 \quad 4$ days

Figure 4. Mitochondria within the smooth muscle of intact resistance arteries display little motility before maintenance in organ culture.

A, Tetramethylrhodamine ethyl ester (TMRE) images acquired at $10 \mathrm{~Hz}$ show little movement of mitochondria in fresh arteries but extensive movement when maintained in organ culture before cannulation and imaging. Scale bars, $10 \mu \mathrm{m}$; tracks of mitochondrial movement were drawn manually for the examples shown; line tracks dilated by 2 pixels to aid visualization. $\mathbf{B}$, The total numbers of mitochondria moving per minute and cells containing moving mitochondria were counted and corrected for mitochondrial area within each region of artery; histograms show mean \pm SE for $n \geq 12$ regions of artery from at least 3 independent artery preparations for each time point $(P>0.05$ [day 1], $P<0.05$ [day 2], $P<0.001$ [day 4] left; $P>0.05$ [day 1], $P<0.01$ [day 2], $P<0.001$ [day 4] right; each cf. control [day 0]). $* P<0.05$ was considered significant. $\mathbf{C}$, Organ culture increased proliferation as measured by immunoblotting for levels of proliferative cell nuclear antigen (PCNA) or Mfn-2. 

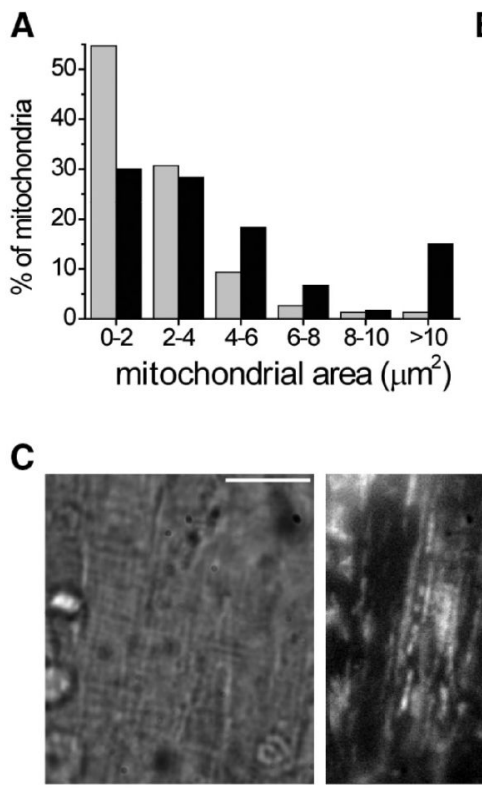

B
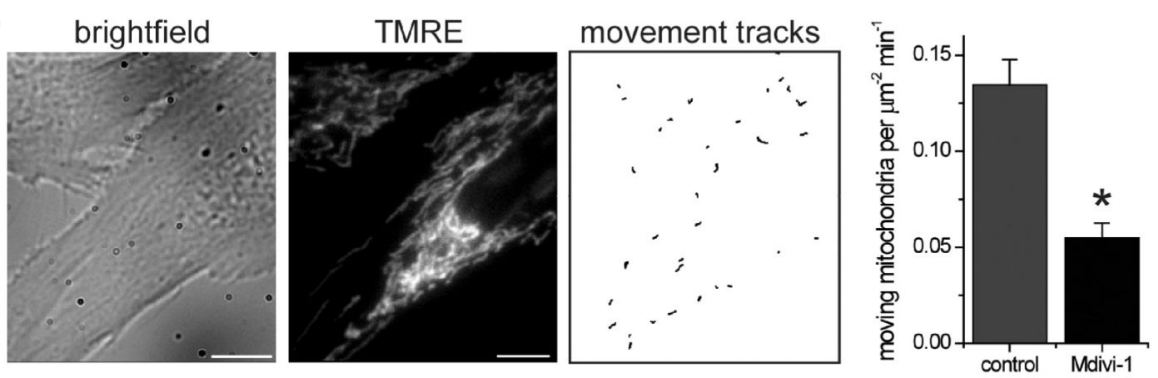

Figure 5. Inhibiting mitochondrial fission prevents mitochondrial motility in cultured smooth muscle cells or artery segments.

A, Cerebral resistance artery cells were maintained in culture for 4 days in the absence or presence of $10 \mu \mathrm{mol} / \mathrm{L}$ Mdivi-1. Cells were then incubated with tetramethylrhodamine ethyl ester (TMRE) and imaged to observe spontaneous flickers of mitochondrial membrane potential, indicating areas of electric (and hence inner mitochondrial membrane) continuity. The area of each mitochondrial flicker was measured for $\geq 60$ mitochondria from $\geq 8$ cells for each of control and Mdivi-1-treated (black bars) cells. B, After 4 days in culture in the presence of $10 \mu \mathrm{mol} / \mathrm{L}$ Mdivi-1, mitochondrial movement was restricted to regions of mitochondria at the periphery of large mitochondrial networks. The histogram shows quantification of the numbers of mitochondria observed to move per minute, corrected for mitochondrial area, for $\mathrm{n} \geq 12$ cells (mean \pm SE; $P<0.001)$. C, Intact resistance artery segments $(\approx 1 \mathrm{~mm}$ length) were maintained in culture conditions for 4 days in the absence or presence (black bars) of $50 \mu \mathrm{mol} / \mathrm{L}$ Mdivi-1. Arteries were then cannulated, pressurized (40 mm Hg), and incubated with TMRE to image mitochondrial motility. The histograms show quantification of the number of mitochondria observed to move and the number of cells containing motile mitochondria per minute, corrected for in-focus mitochondrial area, for $\mathrm{n} \succeq 6$ regions of artery (mean \pm SE; $P<0.001$ for both comparisons). Scale bars, $10 \mu \mathrm{m}$; $* P<0.05$ was considered significant. 

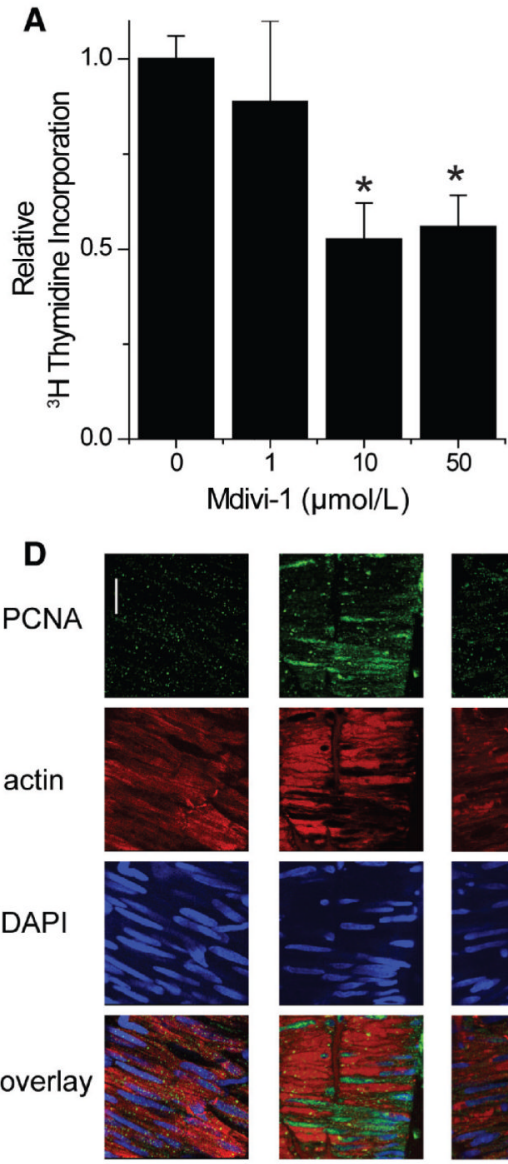

day 0
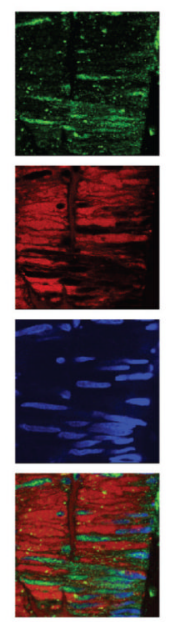

day 4

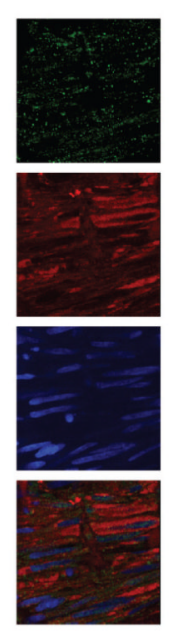

day $4+$ Mdivi-1

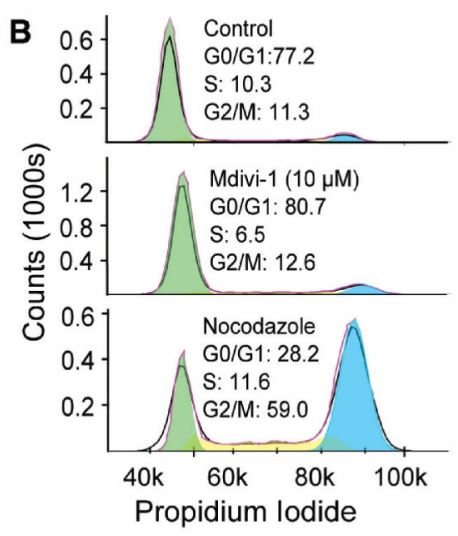

E
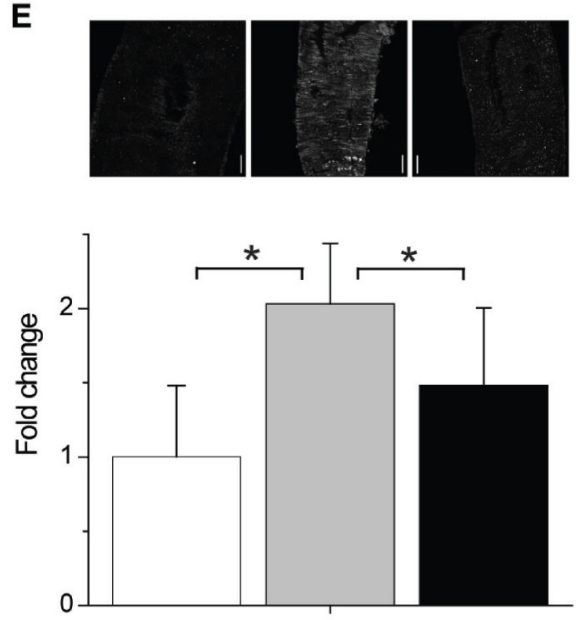

day 0

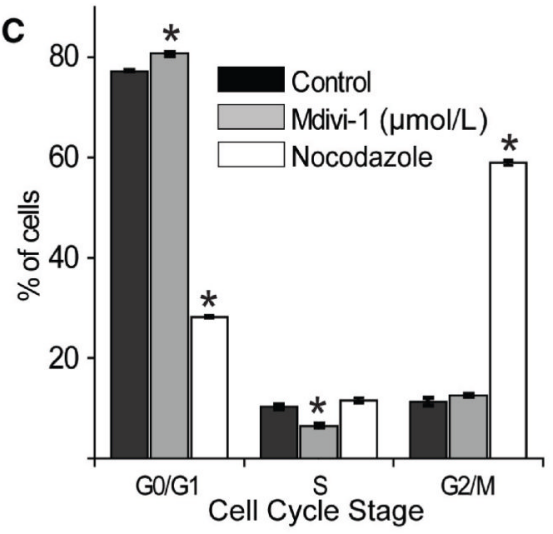

$\mathbf{F}$

Figure 6. Inhibiting mitochondrial motility reduces proliferation in single smooth muscle cells and intact resistance artery.

A, Proliferation of cultured smooth muscle cells, as measured by ${ }^{3} \mathrm{H}$-thymidine incorporation, is inhibited when mitochondrial motility is reduced by Mdivi-1 ( $\mathrm{n}=6$; mean $\pm \mathrm{SE} ; P>0.05[1 \mu \mathrm{mol} / \mathrm{L}], P<0.05[10 \mu \mathrm{mol} / \mathrm{L}]$, and $P<0.05[50 \mu \mathrm{mol} / \mathrm{L}]$ by Kruskal-Wallis independent ANOVA, significance adjusted to account for multiple testing). $\mathbf{B}$, Representative flow-cytometry histograms obtained from control cells and cells in either Mdivi-1 (10 $\mu \mathrm{mol} / \mathrm{L})$ or nocodazole $(50 \mathrm{ng} / \mathrm{mL} ; 476 \mathrm{nmol} / \mathrm{L})$. The plots show the distribution of the cells as a function of propidium iodide fluorescence intensity. The histograms identify 3 distinct populations: cells in G0/G1 (green), S (yellow), or G2/M (blue). Mdivi-1 increased the fraction of cells in G0/G1, and nocodazole increased the fraction of cells in G2/M. C, The percentage of cells in each cell cycle stage was quantified. Mdivi-1 significantly enriched the G0/G1 phase and decreased the S phase. Nocodazole increased the fraction of cells in the G2/M phase and decreased those in the G0/G1 phase $(\mathrm{n}=3$; mean $\pm \mathrm{SE} ; * P<0.05)$. $\mathbf{D}$, Proliferation of resistance artery smooth muscle in the absence and presence of Mdivi-1 as measured by immunocytochemical proliferative cell nuclear antigen (PCNA) staining in smooth muscle a-actin-positive cells of artery segments $(\approx 1 \mathrm{~mm}$ length) pressure-fixed after organ culture for 0 or 4 days. Images show the intact artery labeling of PCNA, smooth muscle actin, nuclei (4',6-diamidino-2-phenylindole), and an overlay of all 3. E, Quantified PCNA immunofluorescence staining from the intact resistance arteries (from experiments like those of $\mathbf{D}$ ) shows that smooth muscle

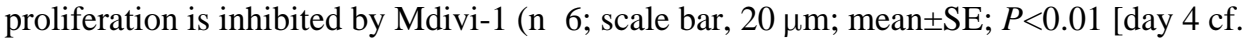


day 0], $P<0.05$ [day 4+Mdivi-1 cf. day 4]). F, Proliferation of cultured smooth muscle cells (as measured by ${ }^{3} \mathrm{H}$-thymidine incorporation) in the absence and presence of the $\mathrm{K}^{+}$channel blocker 4-aminopyridine (4-AP; $10 \mathrm{mmol} / \mathrm{L} ; \mathrm{n}=3$ ). 